\title{
Insect body size changes under future warming projections: a case study of Chironomidae (Insecta: Diptera)
}

\author{
Rungtip Wonglersak (D) Phillip B. Fenberg • Peter G. Langdon • \\ Stephen J. Brooks • Benjamin W. Price
}

Received: 25 June 2020/Revised: 4 April 2021 / Accepted: 16 April 2021 / Published online: 4 May 2021

(C) The Author(s) 2021

\begin{abstract}
Chironomids are a useful group for investigating body size responses to warming due to their high local abundance and sensitivity to environmental change. We collected specimens of six species of chironomids every 2 weeks over a 2 -year period (2017-2018) from mesocosm experiments using five ponds at ambient temperature and five ponds at $4^{\circ} \mathrm{C}$ higher than ambient temperature. We investigated (1) wing length responses to temperature within species and between sexes using a regression analysis, (2) interspecific body size responses to test whether the body size of species influences sensitivity to warming, and (3) the correlation between emergence date and wing length. We found a significantly shorter wing
\end{abstract}

Handling editor: Marcelo S. Moretti

Supplementary Information The online version contains supplementary material available at https://doi.org/10.1007/ s10750-021-04597-8.

R. Wonglersak · P. B. Fenberg

School of Ocean and Earth Science, University of

Southampton, Southampton SO14 3ZH, UK

R. Wonglersak $(\bowtie) \cdot$ P. B. Fenberg •

S. J. Brooks - B. W. Price

Department of Life Sciences, Natural History Museum,

London SW7 5BD, UK

e-mail: r.wonglersak@soton.ac.uk

P. G. Langdon

Department of Geography and Environment, University of

Southampton, Southampton SO17 1BJ, UK length with increasing temperature in both sexes of Procladius crassinervis and Tanytarsus nemorosus, in males of Polypedilum sordens, but no significant relationship in the other three species studied. The average body size of a species affects the magnitude of the temperature-size responses in both sexes, with larger species shrinking disproportionately more with increasing temperature. There was a significant decline in wing length with emergence date across most species studied (excluding Polypedilum nubeculosum and $P$. sordens), indicating that individuals emerging later in the season tend to be smaller.

Keywords Body size response - Climate change Mesocosm · Temperature-size rule (TSR) · Warming temperature

\section{Introduction}

Since the 1990s, climate change as a consequence of anthropogenic activities has become an important issue in ecological, biodiversity and conservation research. The main characteristics of predicted global climate change are a change in precipitation patterns and intensity, stochastic temperature variability, and an increase in the average global mean temperature, that has increased at the rate of $0.08-0.14^{\circ} \mathrm{C}$ per decade since 1951 (Hansen et al., 2006; IPCC, 2014). Furthermore, there is a likely increase of at least $1.5^{\circ} \mathrm{C}$ 
in average global temperature by 2100 for most representative concentration pathways (RCPs) of greenhouse gas emissions (IPCC, 2014).

Change in mean regional temperature affects several aspects of the ecology and life history of species, including their abundance, distribution and body size (e.g., Halpin, 1997; Walther et al., 2002; Thomas et al., 2004). It is generally known that the developmental rate of early life stages in ectotherms depends on environmental temperature, known as the temperature-size rule (TSR) (Atkinson, 1994), which ultimately affects the final adult body size. Adult body size subsequently correlates with individual fitness, population growth, and ecosystem functioning (Bonner \& Peters, 1985). Within species, changes in the final adult body size can affect individual fitness. Particularly among insects, larger females have higher potential fecundity and larger males may have a higher mating success (Elgar \& Pierce, 1988; Berrigan, 1991; Berger et al., 2008). In addition to individual fitness, increasing temperature can relay the effects of changes in body size to species interactions and community dynamics. For example, a reduction in body size in species that are major food resources within a community can indirectly change food web structure and community dynamics by altering feeding rates and predator-prey interactions (Boukal et al., 2019). The ecological effects of body size reductions are more apparent in aquatic ecosystems because food webs of aquatic ecosystems have stronger size-structure than terrestrial habitats (Sentis et al., 2017; Boukal et al., 2019). Thus, understanding how warming affects the body sizes of animals toward the base of the food chain (e.g. chironomids) will allow us to better predict its potential cascading effects on ecological functioning in the future.

Non-biting midges (Diptera: Chironomidae) are a highly diverse aquatic insect family with global distributions (Sæther, 2000; DeWalt et al., 2010). Chironomids are highly abundant, have short generational times, and play a crucial role in aquatic food webs as a resource for other invertebrates, fish and birds. They have different feeding strategies across sub-families, including herbivores, predators, detritivores, grazers and filter-feeders (DeWalt et al., 2010), and there is considerable variation and flexibility in voltinism (Tokeshi, 1995). Additionally, they are considered keystone species as they play an important role in nutrient cycling (Kelly et al., 2004). Changes in chironomid body size can ultimately affect predatorprey relationships. Thus, they are a useful insectmodel to assess the influence of temperature on adult body size.

As found with other arthropods, ambient temperature significantly affects chironomid developmental and growth rate, and ultimately their final adult body size (Pinder, 1986; Sankarperumal \& Pandian, 1991; Stevens, 1998; Mackey, 2006; Frouz et al., 2009), especially in temperate regions where there are large differences between winter and summer temperatures.

Previous laboratory-based studies on chironomids (e.g. McKie \& Cranston, 2005; Frouz et al., 2009; Baek et al., 2012) and in nature (e.g. Oliver, 1971; Pinder, 1986; Kobayashi, 1998) have found a negative correlation between adult body size and temperature. However, other studies have found a bell-shaped relationship between body size and developmental rate, with temperatures above $20^{\circ} \mathrm{C}$ resulting in an increased body size due to a reduced developmental rate (Maier et al., 1990; Frouz et al., 2009; Baek et al., 2012).

In terms of Sexual Size Dimorphism (SSD), a study on Chironomus crassicaudatus Malloch 1915 found steeper declines in the body size of males with increasing temperature than in females (Frouz et al., 2009). Furthermore, studies of Chironomidae recorded faster development of males compared to females (Armitage, 1995; Stevens, 1998). Additionally, the females of many chironomid species have slower development during the last larval instar (Danks, 1978; Stevens, 1998). This is possibly because bigger females are correlated with higher fitness as they could have a bigger clutch size, whereas male fitness does not appear to correlate with body size (Xue \& Ali, 1994). However, a previous study on Chironomus plumosus Linnaeus 1758 found stabilizing selection on male body size. Larger males tend to live longer but have lower mating success, whereas small males might be at an advantage in swarms and could be more aerobatic (Neems et al., 1998). Furthermore, smaller males are faster, which is beneficial for mating success (McLachlan, 1986; Neems et al., 1990), so it may not be important for males to maintain their body size at higher temperatures.

Study of morphological responses of organisms to increasing temperature is complicated because morphology, body size and body shape, could be 
influenced by factors other than temperature, for instance, sexual selection, mortality risk, precipitation or food availability (Tokeshi, 1995). According to studies on other aquatic insects, body size may also vary through the season (Cothran \& Thorp, 1982; Penn, 2015; Wonglersak et al., 2020). A negative correlation between adult body size and emergence date is indicated in previous studies on a tropical stream mayfly (Ephemeroptera) (Sweeney et al., 1995) and many species of British dragonflies (Odonata) (Wonglersak et al., 2020).

Even though there are some laboratory studies on the influence of temperature on chironomid body size (i.e. Oliver, 1971; Pinder, 1986; McKie \& Cranston, 2005; Frouz et al., 2009; Baek et al., 2012), our study approach differs by using mesocosms. These were artificial, outdoor, experimental ponds, with five ponds kept at ambient temperature and five ponds at $4^{\circ} \mathrm{C}$ higher than ambient temperature. As these mesocosms have daily temperature fluctuation they can provide more realistic conditions than indoor laboratory experiments, but are less complicated than natural ecosystems (Kangas \& Adey, 2008). Our study uses mesocosms to investigate intraspecific adult body size responses of chironomids to increasing temperature under a future temperature scenario and the sensitivity of temperature-body size changes between sexes. Additionally, we also investigate interspecific body size responses to temperature by comparing body size change between ambient and heated conditions across species and sex, and explore the correlation between body size and the emergence date of chironomids.

We hypothesized that: (1) a smaller adult body size is expected in the heated treatments due to a faster developmental rate, in agreement with previous studies on chironomids (e.g. Oliver, 1971; Pinder, 1986; Kobayashi, 1998). (2) We expect the magnitude of body size decline with increasing temperature to be higher in large species than small species as suggested by several studies of other invertebrate taxa (Forster et al., 2012; Tseng et al., 2018). (3) The body sizes of adult Chironomidae are expected to be smaller at later emergence dates in both heated and ambient conditions, as larval development rate accelerates to allow emergence before the end of the warm season as found in Odonata (Banks \& Thompson, 1985; Michiels \& Dhondt, 1989; Wonglersak et al., 2020).

\section{Materials and methods}

\section{Sampling}

The experiments were conducted over a two-year period (2017-2018) using ten mesocosm ponds at the Freshwater Biological Association River Laboratory, Dorset, United Kingdom $\left(2^{\circ} 10^{\prime} \mathrm{W}, 50^{\circ} 13^{\prime} \mathrm{N}\right)$. The ten mesocosm ponds have been fully functioning since 2006 (Yvon-Durocher et al., 2010). Each pond has a $2.5 \mathrm{~m}^{2}$ surface area with $1.8 \mathrm{~m}$ diameter and contains about $1 \mathrm{~m}^{3}$ of water that may vary seasonally. These ponds consist of five ponds at ambient temperature, and five artificially warmed to remain $4^{\circ} \mathrm{C}$ above ambient temperature at all times (see mean daily temperature in Fig. S1). The mesocosms are warmed by a heating element connected to a thermal couple (Fig. 1), which monitors the temperature of both warmed and ambient ponds. The initial colonization of species started in 2005 with organisms from surrounding habitats, with the exception of fish, which are the main predators of freshwater invertebrates (YvonDurocher et al., 2015). All the ponds are unshaded and have similar environmental conditions, especially in terms of water temperature, trophic conditions, and aquatic vegetation.

A floating emergence trap, covering $0.25 \mathrm{~m}^{2}$, was put into each of the ten mesocosms (Fig. 1). All insects were collected from the traps every 2 weeks, preserved in absolute ethanol and kept in a refrigerator until processed. Specimens were collected through

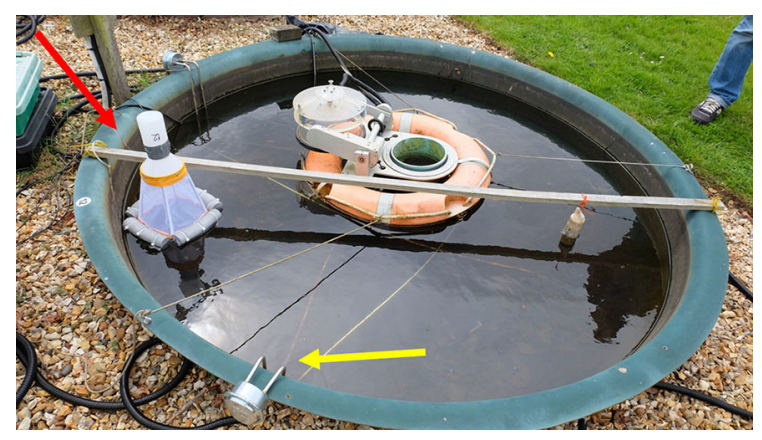

Fig. 1 The mesocosms at Freshwater Biological Association (FBA), River Laboratory, East Stoke, Dorset, UK. Each pond has a $2.5 \mathrm{~m}^{2}$ surface area with $1.8 \mathrm{~m}$ diameter and contains about $1 \mathrm{~m}^{3}$ of water that may vary seasonally. Heated ponds are warmed by a heating element connected to a thermocouple (yellow arrow). Emergence traps (red arrow) were put into each of ten ponds ( 5 traps in ambient ponds, 5 traps in heated ponds) 
spring, summer and autumn from 4th May 2017 to 16th November 2017, and 28th February 2018 to 10th October 2018.

\section{Identification}

Six chironomid species, including males and females of Ablabesmyia monilis Linnaeus $1758(\mathrm{~N}=256)$, Chironomus piger Strenzke $1956(\mathrm{~N}=191)$, Tanytarsus nemorosus Edwards 1929 ( $\mathrm{N}=905)$, Procladius crassinervis Zetterstedt $1838(\mathrm{~N}=488)$, and males of Polypedilum nubeculosum Maigen $1804(\mathrm{~N}=87)$ and Polypedilum sordens van de Wulp $1874(\mathrm{~N}=49)$, were identified and selected for the study based on the availability of specimens collected from the mesocosms (Table 1). Female Polypedilum spp. could not be separated by morphology, thus only male specimens were used.

All specimens were initially sorted by morphotype and only species with more than 100 specimens were selected for analysis. As only males can be reliably identified to species from morphology (Langton \& Pinder, 2007), a male specimen from each morphotype was selected and used as a reference specimen for morphological identification. The wings were removed from the reference specimen and mounted on a microscope slide using HYDRO-MATRIX ${ }^{\circledR}$, permanent mounting medium. Following this the rest of the specimen was heated at $70^{\circ} \mathrm{C}$ in $10 \% \mathrm{KOH}$ for 5-10 min, washed in glacial acetic acid and then water, and finally mounted on the same slide as the wings. Species were identified following Langton \& Pinder (2007).

DNA barcoding for species identification

DNA barcoding was used to confirm the morphological species identifications and to link females of each species to the identified males. However, the females of Polypedilum nubeculosum and $P$. sordens could not be distinguished morphologically to species and so females of these species were not included in this study. Representative specimens from each morphospecies were extracted using either the Qaigen DNEasy Blood and Tissue kit or a 5\% Chelex solution (Walsh et al., 1991). DNA barcoding followed standard inhouse protocols using LCO1490 and HCO2198 primers (Folmer et al., 1994). Each reaction consisted of $1 \mathrm{mM}$ total dNTPs, $3 \mathrm{mM} \mathrm{MgCl2}, 1.25 \mathrm{u}$ Bio-Taq DNA polymerase (Bioline), $0.1 \mu \mathrm{M}$ each primer and $1 \mathrm{x}$ reaction buffer. Cycling conditions were: initial denaturation $94^{\circ} \mathrm{C}$ for $1 \mathrm{~min}$ followed by 35 cycles of $94^{\circ} \mathrm{C}$ for $30 \mathrm{~s}, 48^{\circ} \mathrm{C}$ for $30 \mathrm{~s}$ and $72^{\circ} \mathrm{C}$ for $30 \mathrm{~s}$, with a final elongation of $10 \mathrm{~min}$ at $72^{\circ} \mathrm{C}$. $\mathrm{PCR}$ products were visualised using gel electrophoresis, purified using Agencourt AMPure XP beads and then sequenced bi-

Table 1 Species and numbers of chironomids used in this study

\begin{tabular}{|c|c|c|c|c|c|c|c|}
\hline \multirow[t]{2}{*}{ Subfamily (tribe) } & \multirow[t]{2}{*}{ Species } & \multirow{2}{*}{$\begin{array}{l}\text { Feeding } \\
\text { strategies }\end{array}$} & \multicolumn{2}{|l|}{ Female } & \multicolumn{2}{|l|}{ Male } & \multirow{2}{*}{$\begin{array}{l}\text { Number of } \\
\text { specimens }\end{array}$} \\
\hline & & & Ambient & Heated & Ambient & Heated & \\
\hline $\begin{array}{l}\text { Tanypodinae } \\
\text { (Pentaneurini) }\end{array}$ & Ablabesmyia monilis & Predator & 45 & 97 & 36 & 78 & 256 \\
\hline $\begin{array}{l}\text { Chironominae } \\
\text { (Chironomini) }\end{array}$ & Chironomus piger & $\begin{array}{l}\text { Collector } \\
\text { (Gatherer) }\end{array}$ & 45 & 44 & 56 & 46 & 191 \\
\hline $\begin{array}{l}\text { Tanypodinae } \\
\text { (Procladiini) }\end{array}$ & $\begin{array}{l}\text { Procladius } \\
\quad \text { crassinervis }\end{array}$ & Predator & 139 & 91 & 137 & 121 & 488 \\
\hline $\begin{array}{l}\text { Chironominae } \\
\text { (Tanytarsini) }\end{array}$ & Tanytarsus nemorosus & $\begin{array}{l}\text { Collector } \\
\text { (Filterer) }\end{array}$ & 236 & 287 & 198 & 184 & 905 \\
\hline \multirow[t]{2}{*}{$\begin{array}{l}\text { Chironominae } \\
\text { (Chironomini) }\end{array}$} & $\begin{array}{l}\text { Polypedilum } \\
\text { nubeculosum }\end{array}$ & $\begin{array}{l}\text { Collector } \\
\text { (Gatherer) }\end{array}$ & - & - & 53 & 34 & 87 \\
\hline & Polypedilum sordens & $\begin{array}{l}\text { Collector } \\
\text { (Gatherer) }\end{array}$ & - & - & 23 & 26 & 49 \\
\hline Total & & & & & & & 1,976 \\
\hline
\end{tabular}

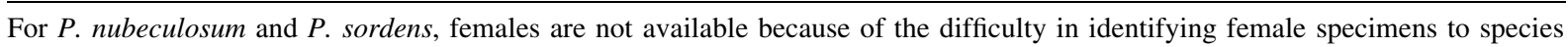


directionally using BigDye terminator reaction mix v3.1 in a 3730x1 DNA analyser (Applied Biosystems) at the NHM sequencing facility. Sequences were deposited in GenBank (Accession numbers is MW448368-MW448379).

\section{Data acquisition}

The right wing of all specimens was removed and slide-mounted. All wings were imaged using either a Canon 5DsR camera and MPE-65 lens or ZEISS Axio Scan $z 1$, both at $5 x$ magnification.

Wing length was used as previous studies have shown wing length is a good proxy for body size (McLachlan, 1986; Ali, 1994; Xue \& Ali, 1994; Fyodorova \& Azovsky, 2003). Images of wings with scale were measured using ImageJ (version 1.51). The scale was set in ImageJ using the scale bar to measure for a known distance (the image resolution was 1222 pixels per $\mathrm{mm}$ ). Each right wing was measured from the humeral cross-vein (HC) to the end of costal extension (CE) (Fig. 2). To confirm the precision of wing length measurements, 50 specimens were remeasured, and a correlation analysis between the original wing lengths and remeasured wing lengths was performed. We found a very high correlation between original wing length measurements and remeasurements ( $r=0.99, P<0.001$ ). Wing images used in this study are available on the NHM data portal (https://doi.org/10.5519/0003569). Specimens within each species collected from different mesocosms were pooled by temperature treatment for analysis to increase the sample size. Data analysed from 2011 to 2012 showed that an individual mesocosm has no effect on community structure, especially on the phytoplankton community (Yvon-Durocher et al., 2015) which is a dominant food resource for chironomids (Armitage, 1995). Nevertheless, the

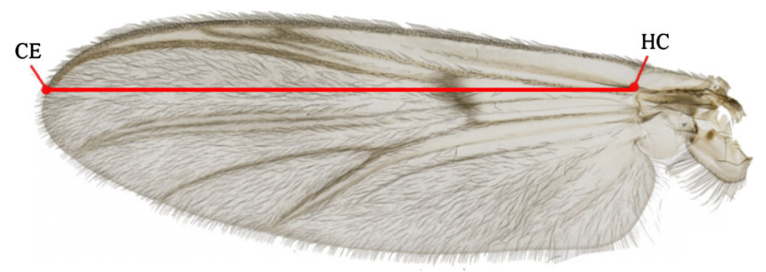

Fig. 2 Wing morphology of Polypedilum sordens and wing length measurement from humeral cross-vein (HC) to the end of costal extension (CE) community structure and species in these ponds may have changed since this date and thus the mesocosms may not constitute exact replicates.

Individual species analysis

All analyses were performed in $\mathrm{R}$ (version 1.2.5033) ( $\mathrm{R}$ Core Team, 2014). Within each species, generalised linear models (GLMs) were performed twice to explore the influence of the independent variables including temperature condition, year and emergence date, on wing length which is a dependent variable. First, a full model was developed to explore the effects of temperature condition, emergence date, sex and year on wing length. A second, reduced model which excluded year from the set of independent variables was then run. The full and reduced models were compared using the Akaike Information Criterion (AIC) (Table S1) to select the most parsimonious model.

In order to examine the effect of warming on wing length, a one-way ANOVA and a Tukey's post-hoc test were used to test the difference in mean wing length between ambient and heated conditions. The relationship between emergence date and wing length was examined with a linear regression (Kenney \& Keeping, 1962). A locally weighted regression was fitted to the model (Cleveland \& Devlin, 1988) if species exhibited non-linear patterns.

Interspecific analysis

The percentage wing length change between treatments was calculated from mean wing length change between ambient and heated conditions for each sex of each species (Table S2) using the following formula; $\left(\frac{\bar{x}_{\text {heated }}-\bar{x}_{\text {ambient }}}{\bar{x}_{\text {ambient }}} \times 100\right)$. Then to investigate if species' size is related to sensitivity to temperature, a linear regression analysis was performed between the percent change of wing length between treatments and mean wing length of each species and sex.

\section{Results}

The reduced model GLM, which excluded year, of each species is shown in Table 2 as the AIC approach indicated that a model without year explained the 
Table 2 The generalized linear model analysis of Chironomids species in this study

\begin{tabular}{|c|c|c|c|c|c|c|}
\hline & \multicolumn{6}{|l|}{ Wing length } \\
\hline & A. monilis & C. piger & P. crassinervis & T. nemorosus & $\begin{array}{l}P . \\
\text { nubeculosum }\end{array}$ & P. sordens \\
\hline Emergence date & $\begin{array}{l}-0.003 \\
\quad( \pm 0.001)^{* * *}\end{array}$ & $\begin{array}{l}-0.003 \\
\quad( \pm 0.001)^{* * *}\end{array}$ & $\begin{array}{l}-0.005 \\
\quad( \pm 0.001)^{* * *}\end{array}$ & $\begin{array}{l}-0.007 \\
\quad( \pm 0.001)^{* * *}\end{array}$ & $\begin{array}{l}-0.001 \\
\quad( \pm 0.001)\end{array}$ & $-0.001( \pm 0.001)$ \\
\hline $\begin{array}{l}\text { Temperature } \\
\text { condition }\end{array}$ & $\begin{array}{l}-0.064 \\
\quad( \pm 0.034)\end{array}$ & $\begin{array}{l}-0.497 \\
\quad( \pm 0.049)\end{array}$ & $\begin{array}{l}-0.497 \\
\quad( \pm 0.045)^{* * *}\end{array}$ & $\begin{array}{l}-0.276 \\
\quad( \pm 0.023)^{* * *}\end{array}$ & $\begin{array}{l}-0.076 \\
\quad( \pm 0.023)\end{array}$ & $-0.245( \pm 0.051)^{* * *}$ \\
\hline Sex & $\begin{array}{l}0.201 \\
\quad( \pm 0.032)^{* * *}\end{array}$ & $\begin{array}{l}-0.204 \\
\quad( \pm 0.043)^{* * *}\end{array}$ & $0.025( \pm 0.045)$ & $\begin{array}{l}0.107 \\
\quad( \pm 0.024)^{* * *}\end{array}$ & NA & NA \\
\hline $\begin{array}{l}\text { Degrees of } \\
\text { freedom }\end{array}$ & 252 & 187 & 484 & 901 & 83 & 46 \\
\hline
\end{tabular}

A negative symbol shows a negative relationship between wing length and the variables. Significant levels are indicated as $* * *$ for $P<0.001$

variation of wing length better than the full model including year. The regression indicated a strong significant negative $(P<0.001)$ effect of temperature condition (ambient vs ambient $+4^{\circ} \mathrm{C}$ ) on wing length in three species: Polypedilum sordens, Procladius crassinervis and Tanytarsus nemorosus (Table 2). Also, a one-way ANOVA indicated significantly longer wing lengths in the ambient mesocosms than heated mesocosms in both sexes of Procladius crassinervis and Tanytarsus nemorosus $(P<0.001)$ and in males of Polypedilum sordens $(P<0.001)$ (Table 2; Fig. 3). Whereas, a non-significant difference in wing length between temperature conditions in both sexes of Chironomus piger and Ablabesmyia monilis, and male Polypedilum nubeculosum was found (Table 2; Fig. 3).

With respect to seasonal clines in wing length, significantly smaller wing lengths were found when adults emerged later in the season in the linear regressions of both sexes and both temperature conditions in A. monilis, C. piger, $P$. crassinervis and T. nemorosus (Fig. 4a-d). While Polypedilum nubeculosun and $P$. sordens exhibited non-significant seasonal cline in wing length (Fig. 4e, f). Additionally, a quadratic local regression exhibited obvious U-shaped curves between wing length and emergence date in $P$. crassinervis (Fig. 4c).

In terms of interspecific responses, all species, excluding $C$. piger, showed a negative percent wing length change between ambient and heated conditions in both sexes (Fig. 5). The range of wing length changes between treatments is from $+0.84 \%$ to
$-9.68 \%$ in females and from $+2.68 \%$ to $-9.60 \%$ in males. However, correlations between percent change of wing length and mean wing length of each species are non-significant ( $r=-0.69$ and $-0.06, P>0.05$, in females and males, respectively), likely due to the limited number of species in this study.

\section{Discussion}

Although this study finds no universal pattern in the response of wing size to temperature among the chironomid species examined, we find that species either tend to get smaller under heated conditions or show non-significant body size changes. Interestingly, a significant seasonal decline in wing length is exhibited across four species in this study: A. monilis, C. piger, $P$. crassinervis and T. nemorosus, in both heated and ambient conditions. Below we discuss the likely cause of these responses and their consequences.

Although each species in our study tend to have shorter wings in heated conditions than ambient conditions across the emergence season, this relationship is strongly significant in both sexes of Procladius crassinervis, $T$. nemorous and male Polypedilum sordens. This finding highlights that adult body size of these species gets smaller with increasing temperature. This result corresponds well with the temperature-size rule (TSR) (Atkinson, 1994) which found that the developmental rate of ectotherms is faster at warmer temperatures, consequently, adult size should 


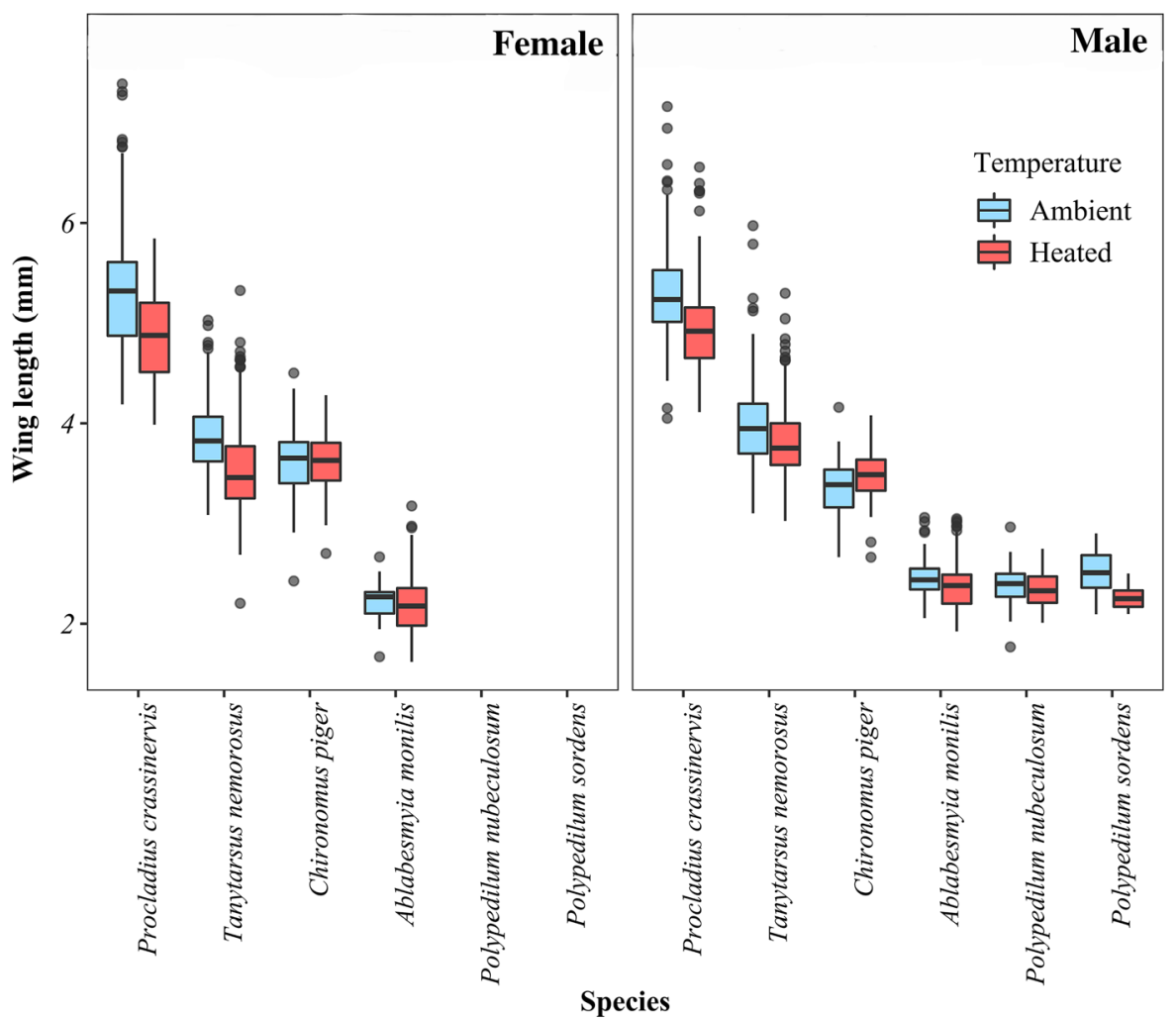

Fig. 3 Box plots of the wing lengths of specimens between ambient and heated conditions for females (left) and males (right) of six chironomid species. For $P$. nubeculosum and $P$.

be smaller in warm environments compared to individuals growing in cooler temperatures (i.e. Pinder, 2002; Mackey, 2006; Frouz et al., 2009). However, we found a non-significant warming effect on wing length in A. monilis, C. piger and P. nubeculosum.

These inconsistent body size-temperature responses between species may be influenced by differences in their life-history, particularly, the number of generations per year. A previous study on various arthropods suggested that voltinism is associated with temperature-size responses (Horne et al., 2015). Species with one generation per year (univoltine) tend to have non-significant or positive temperature-size responses, whereas species with multiple generations per year (multivoltine species) tend to support predications of the TSR (Atkinson, 1994). In our study, plots between number of specimens collected versus emergence date of each species (Fig. S2) show that A. monilis has a univoltine life cycle (one generation per year). Chironomus piger, $P$. nubeculosum and $P$. sordens likely have a univoltine sordens, the results of female wing length are not available because of the difficulty in identifying female specimens to species. Significant results indicated by $* * *(P<0.001)$

or bivoltine life cycle (one or two generations per year). While $P$. crassinervis and $T$. nemorosus, which exhibit a negative correlation between wing length and temperature, likely have a multivoltine life cycle (more than two generations per year). Thus, voltinism type could potentially explain these different responses between species. However, more work on the life-history of these species is essential for a more complete understanding of the underlying factors driving the different temperature-size responses we observed.

Our results do not show different temperature-size responses between the sexes. This result is inconsistent with previous studies (Xue \& Ali, 1994; Frouz et al., 2009) and does not support our hypothesis that females will retain their body size to maximise fecundity, whereas small males will be at an advantage for swarming and mating success (McLachlan, 1986; Neems et al., 1990). However, sexual size dimorphism and the temperature-body size response in each sex of chironomids requires additional life-history data and 
Fig. 4 A regression plot of generalised linear models of wing length vs emergence date (number of the day) in females and males of six chironomid species. For Procladius crassinervis, local regression was applied because this species exhibits obvious U-shaped curves between wing length and emergence date. For Polypedilum nubeculosum and $P$. sordens, the results of female wing length are not available because of the difficulty in identifying female specimens to species. Red dots and lines represent heated $\left(+4^{\circ} \mathrm{C}\right)$ conditions and blue dots and lines represent ambient condition (a) Ablabesmyia monilis

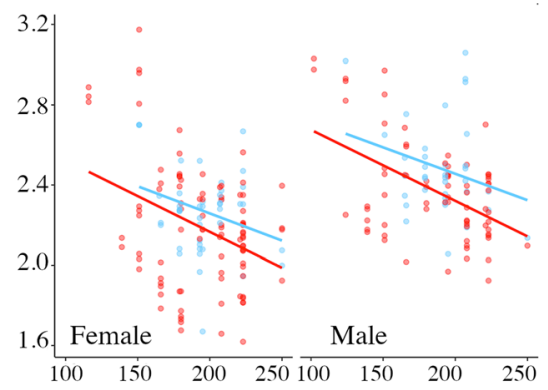

(c) Procladius crassinervis

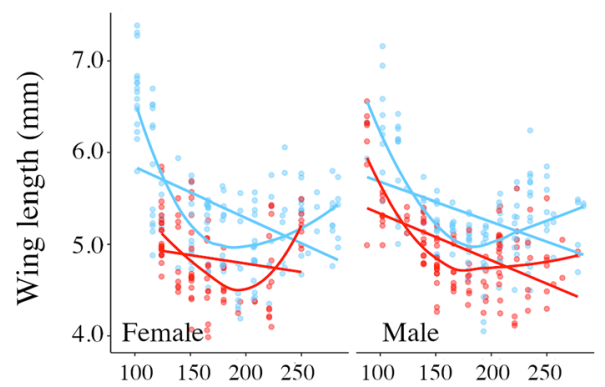

(e) Polypedilum nubeculosum

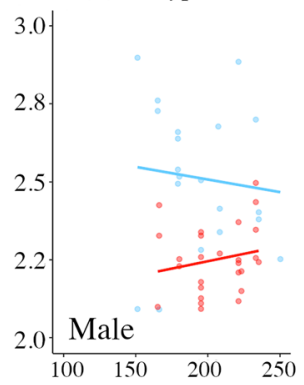

(b) Chironomus piger

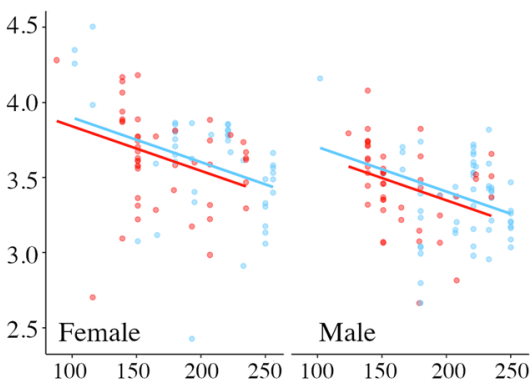

(d) Tanytarsus nemorosus

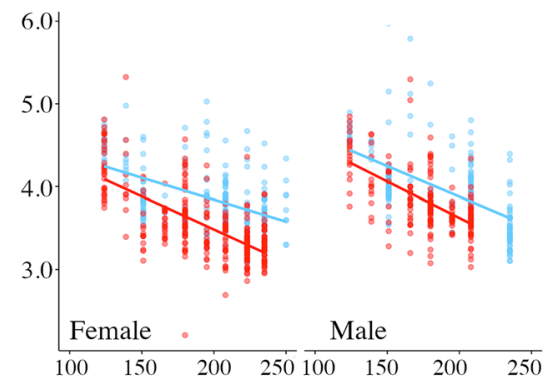

(f) Polypedilum sordens

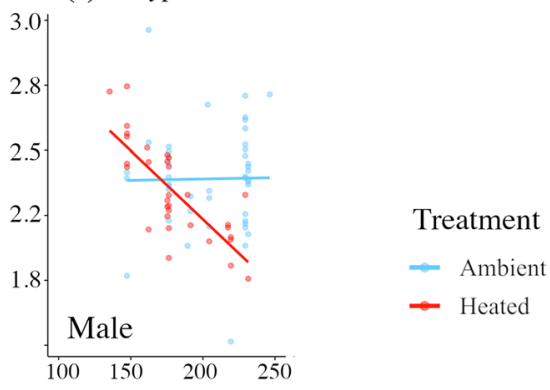

Emergence date

further study to examine if the previously reported differential sensitivity between the sexes is applicable to the group more widely.

When comparing the response between species, there was a non-significant negative correlation between mean wing length and the percent change in wing length between treatments in both sexes. This is probably because of the limited number of species in this study. This response contrasts with a recent study on Odonata which found larger species do not respond more to temperature than smaller species, however, this may have been due to the territorial nature of the larger Anisoptera (Wonglersak et al., 2020). Most anisopteran species are strongly territorial where large male body size is linked to mating success
(Sokolovska et al., 2000; Córdoba-Aguilar, 2008). Thus, small larvae of Anisoptera may delay their emergence to emerge as larger adults later in the season, therefore increasing their territorial competitiveness. While chironomids have been reported to exhibit territorial feeding behaviour in the larval stage of some species, this does not correlate with body size (Brodin \& Andersson, 2009; Imada, 2020). Our results suggest that larger species tend to have a greater reduction in body size with increasing temperature than smaller species, consistent with previous aquatic and terrestrial studies (Forster et al., 2012; Horne et al., 2015; Tseng et al., 2018). The 'oxygen limitation hypothesis' might account for this pattern of interspecific responses (Woods, 1999) - warmer water 


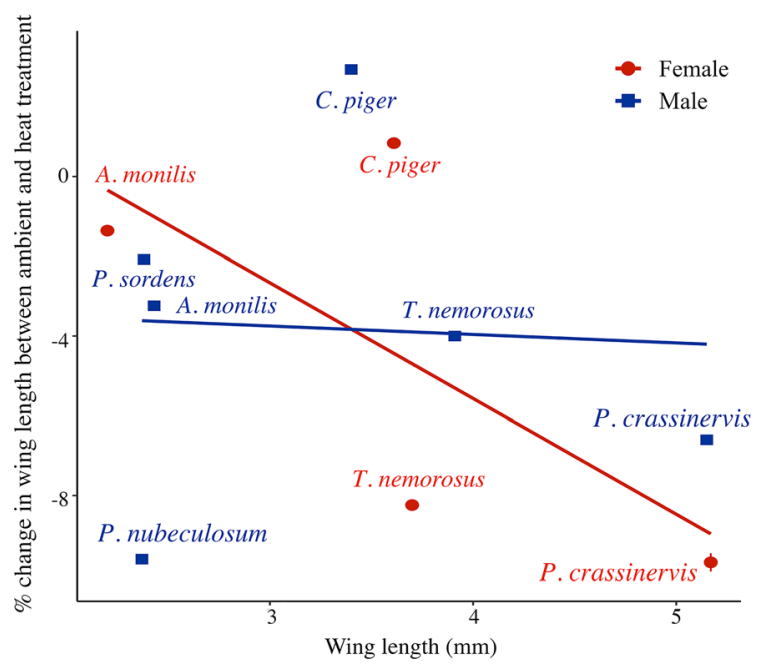

Fig. 5 Percentage change in mean wing length between ambient and heated treatments for each species plotted against the mean wing length of each species. A correlation analysis indicated a non-significant negative correlation between percent change in wing length between treatments and average wing length per species in females (red) $(r=-0.69, P>0.05)$ and males (blue) $(r=-0.06, P>0.05)$

holds less oxygen than cooler water which can exacerbate the increased energetic cost of respiration in larger aquatic invertebrates (Woods, 1999; Forster et al., 2012). A previous study of these mesocosms showed that the level of oxygen concentration is significantly lower in the warmed ponds than the ambient ones $(P<0.001)$ (Zhu et al., 2020). Thus, larger chironomids would get disproportionately smaller than smaller species in warmer temperatures, however, this hypothesis requires more species to be studied.

With respect to a seasonal cline in wing length, the results indicate a significantly smaller wing length with a later emergence date in four species (in both heated and ambient conditions): A. monilis, C. piger, $P$. crassinervis and T. nemorosus. We hypothesise that larval development accelerates as the end of the warm season approaches, leading to smaller adults later in the season (Johansson \& Rowe, 1999). The nonsignificant seasonal size-cline in Polypedilum nubeculosum and $P$. sordens may be an artifact resulting from the limited number of specimens available for our study.

Clear U-shaped curves between wing length and emergence date were observed in $P$. crassinervis. These U-shaped patterns could be a reflection of body size-temperature responses across the year. Individuals emerging early during spring and later in autumn when temperatures are cool tend to have a bigger size than those emerging when it is warmer during summer. Some chironomid species undergo larval diapause during unfavourable conditions (Oliver, 1971; Neumann \& Krüger, 1985). We presumed that P. crassinervis probably adapts to winter temperature by arresting larval development during the winter months. Ultimately, bigger adult size early in the emergence season compensates for their larval diapause. The other species in this study probably avoid larval diapause and are forced to emerge before winter leading to smaller adults (McLachlan et al., 1995). However, this assumption must be evaluated further by investigating the life cycle and phenology of these species. Finally, while we have explored the influence of warming on the body size of some chironomid species, other biotic factors in natural ecosystems, such as predators, can also result in selection pressure which ultimately affects the body size of prey.

\section{Conclusion}

Our results suggest that predicted future temperatures will likely lead to a reduction in the adult body size of some chironomids in both sexes. Larger-bodied species will likely be more negatively affected by increasing temperatures than smaller species. In particular, this reduction in body size has the potential to affect trophic interactions, especially predator-prey interactions. Chironomids are primary prey for other invertebrates, fish and birds, and smaller prey can affect the nutritional value per individual, attack rate, and handling time of predator-prey interactions (Thompson, 1975). However, we do not show a single consistent response to temperature across all species studied. Therefore, future studies should include additional species and seek a better understanding of the influence of life-cycles on body size response to temperature across the emergence period.

Acknowledgements The authors thank to John Davy-Bowker (Freshwater Biological Association) for his help and support with the mesocosms. This project is funded by the Royal Thai Government.

Author contributions RW collected and analysed the data and led the writing of the paper. PBF, PGL, SJB and BWP helped 
conceive the ideas for the research and analyses and provided direction for the writing.

Data accessibility The R scripts used for data analyses and the specimen data, including collecting date, wing length and corresponding temperature data are available at: https://doi.org/ $10.5519 / 0003569$.

\section{Declarations}

Conflict of interest The authors declare that there is no conflict of interest.

Open Access This article is licensed under a Creative Commons Attribution 4.0 International License, which permits use, sharing, adaptation, distribution and reproduction in any medium or format, as long as you give appropriate credit to the original author(s) and the source, provide a link to the Creative Commons licence, and indicate if changes were made. The images or other third party material in this article are included in the article's Creative Commons licence, unless indicated otherwise in a credit line to the material. If material is not included in the article's Creative Commons licence and your intended use is not permitted by statutory regulation or exceeds the permitted use, you will need to obtain permission directly from the copyright holder. To view a copy of this licence, visit http://creativecommons.org/licenses/by/4.0/.

\section{References}

Ali, A., 1994. Oviposition, fecundity, and body size of a pestiferous midge, Chironomus crassicaudatus (Diptera: Chironomidae). Environmental Entomology 23: 1480-1484.

Armitage, P. D., 1995. Behaviour and ecology of adults. In The Chironomidae, P. D. Armitage, P. S. Cranston, L. C. V. Pinder (eds). Springer. Dordrecht, Netherland

Atkinson, D., 1994. Temperature and organism size: a biological law for ectotherms? Advances in Ecological Research 25: $1-58$.

Baek, M. J., T. J. Yoon \& Y. J. Bae, 2012. Development of Glyptotendipes tokunagai (Diptera: Chironomidae) under different temperature conditions. Environmental Entomology 41: 950-958.

Banks, M. J. \& D. J. Thompson, 1985. Lifetime mating success in the damselfly Coenagrion puella. Animal Behaviour 33: 1175-1183.

Berger, D., R. Walters \& K. Gotthard, 2008. What limits insect fecundity? Body size- and temperature-dependent egg maturation and oviposition in a butterfly. Functional Ecology 22: 523-529.

Berrigan, D., 1991. The allometry of egg size and number in insects. Oikos 60: 313-321.

Bonner, N. \& R. H. Peters, 1985. The Ecological Implications of Body Size. Cambridge University Press, Cambridge.

Boukal, D. S., A. Bideault, B. M. Carreira \& A. Sentis, 2019. Species interactions under climate change: connecting kinetic effects of temperature on individuals to community dynamics. In Current Opinion in Insect Science.

Brodin, Y. \& M. H. Andersson, 2009. The marine splash midge Telmatogon japonicus (Diptera; Chironomidae)-extreme and alien? Biological Invasions 11: 1311-1317.

Córdoba-Aguilar, A., 2008. Dragonflies and Damselflies: Model Organisms for Ecological and Evolutionary Research. In Córdoba-Aguilar. A. (ed), Dragonflies and Damselflies: Model Organisms for Ecological and Evolutionary Research. Oxford University Press.

Cothran, M. L. \& J. H. Thorp, 1982. Emergence patterns and size variation of Odonata in a thermal reservoir. Freshwater Invertebrate Biology 1: 30-39.

Cleveland, W. S., \& S. J. Devlin, 1988. Locally weighted regression: an approach to regression analysis by local fitting. Journal of the American Statistical Association.

Danks, H. V., 1978. Some effects of photoperiod, temperature, and food on emergence in three species of chironomidae (diptera). The Canadian Entomologist 110: 289-300.

DeWalt, R. E., V. H. Resh \& W. L. Hilsenhoff, 2010. Diversity and classification of insects and collembola. In Thorp, J. H. \& A. P. Covich (eds), Ecology and Classification of North American Freshwater Invertebrates. Academic Press, Cambridge 587-657.

Elgar, M. A., \& N. E. Pierce, 1988. Mating success and fecundity in an ant-tended lycaenid butterfly. In Reproductive success: studies of individual variation in contrasting breeding systems 59-75.

Folmer, O., M. Black, W. Hoeh, R. Lutz \& R. Vrijenhoek, 1994. DNA primers for amplification of mitochondrial cytochrome c oxidase subunit I from diverse metazoan invertebrates. Molecular Marine Biology and Biotechnology 3: 294-299.

Forster, J., A. G. Hirst \& D. Atkinson, 2012. Warming-induced reductions in body size are greater in aquatic than terrestrial species. Proceedings of the National Academy of Sciences 109: 47.

Frouz, J., A. Ali \& R. J. Lobinske, 2009. Influence of temperature on developmental rate, wing length, and larval head capsule size of pestiferous midge Chironomus crassicaudatus (Diptera: Chironomidae). Journal of Economic Entomology 95: 699-705.

Fyodorova, M. V. \& A. I. Azovsky, 2003. Interactions between swarming Chironomus annularius (Diptera: Chironomidae) males: Role of acoustic behavior. Journal of Insect Behavior 16: 295-306.

Halpin, P. N., 1997. Global climate change and natural-area protection: management responses and research directions. Ecological Applications 7: 828-843.

Hansen, J., M. Sato, R. Ruedy, K. Lo, D. W. Lea \& M. MedinaElizade, 2006. Global temperature change. Proceedings of the National Academy of Sciences of the United States of America 103: 14288-14293.

Horne, C. R., A. G. Hirst \& D. Atkinson, 2015. Temperaturesize responses match latitudinal-size clines in arthropods, revealing critical differences between aquatic and terrestrial species. Ecology Letters 18: 327-335.

Imada, Y., 2020. A novel leaf-rolling chironomid, eukiefferiella endobryonia sp. Nov. (Diptera, Chironomidae, Orthocladiinae), highlights the diversity of underwater chironomid tube structures. ZooKeys 906: 73-111. 
IPCC, 2014. Climate Change 2014. In Climate Change 2014: Synthesis Report.

Johansson, F. \& L. Rowe, 1999. Life history and behavioral responses to time constraints in a damselfly. Ecology 80: 1242-1252.

Kangas, P. C. \& W. H. Adey, 2008. Mesocosm Management. Encyclopedia of Ecology: 2308-2313.

Kelly, A., R. I. Jones \& J. Grey, 2004. Stable isotope analysis provides fresh insights into dietary separation between Chironomus anthracinus and C. plumosus. Journal of the North American Benthological Society.

Kenney, J. F. \& E. S. Keeping, 1962. Linear Regression and Correlation. In, Mathematics of Statistics, Van Nostrand (ed). Princeton 252-285.

Kobayashi, T., 1998. Seasonal changes in body size and male genital structures of Procladius choreus (Diptera: Chironomidae: Tanypodinae). Aquatic Insects 20: 165-172.

Langton, P.H. \& L. C. V. Pinder, 2007. Keys to the Adult Male Chironomidae of Britain and Ireland, D. W. Sutcliffe (1st ed.). Freshwater Biological Asssociation.

Mackey, A. P., 2006. Growth and development of larval Chironomidae. Oikos 28: 270-275.

Maier, K. J., P. Kosalwat \& A. W. Knight, 1990. Culture of Chironomus decorus (Diptera: Chironomidae) and the effect of temperature on its life history. Environmental Entomology 19: 1681-1688.

McKie, B. G. \& P. S. Cranston, 2005. Size matters: systematic and ecological implications of allometry in the responses of chironomid midge morphological ratios to experimental temperature manipulations. Canadian Journal of Zoology 83: 553-568.

McLachlan, A. J., 1986. Sexual dimorphism in midges: strategies for flight in the rain-pool dweller Chironomus imicola (Diptera: Chironomidae). The Journal of Animal Ecology 55: 261-267.

McLachlan, A., P. Armitage, P. S. Cranston \& L. C. V. Pinder, 1995. The Chironomidae. The Biology and Ecology of Non-biting Midges. In L. C. V. Armitage, P.D., Cranston, P.S., Pinder (ed.), The Journal of Animal Ecology. Chapman \& Hall 64.

Michiels, N. K. \& A. A. Dhondt, 1989. Effects of emergence characteristics on longevity and maturation in the dragonfly Sympetrum danae (Anisoptera: Libellulidae). Hydrobiologia 171: 149-158.

Neems, R. M., A. J. McLachlan \& R. Chambers, 1990. Body size and lifetime mating success of male midges (Diptera: Chironomidae). Animal Behaviour 40: 648-652.

Neems, M., J. Lazarus Rachel \& A. J. McLachlan, 1998. Lifetime reproductive success in a swarming midge: trade-offs and stabilizing selection for male body size. Behavioral Ecology 9: 279-286.

Neumann, D. \& M. Krüger, 1985. Combined effects of photoperiod and temperature on the diapause of an intertidal chironomid.

Oliver, D. R., 1971. Life history of the Chironomidae. Annual Review of Entomology 16: 211-230.

Penn, G. H., 2015. Seasonal variation in the adult size of Pachydiplax Longipennis (Burmeister) (Odonata, Libellulidae). Annals of the Entomological Society of America 44: 193-197.
Pinder, L. C. V., 1986. Biology of freshwater Chironomidae. Annual Review of Entomology 31: 1-23.

Pinder, L., 2002. Biology of Freshwter Chironomidae. Annual Review of Entomology.

R Core Team, 2014. R: A language and environment for statistical computing. R Foundation for Statistical Computing, Vienna, Austria. http://www.R-project.org/.

Sæther, O. A., 2000. Zoogeographical patterns in Chironomidae (Diptera). SIL Proceedings 27: 1922-2010.

Sankarperumal, G. \& T. J. Pandian, 1991. Effect of temperature and chlorella density on growth and metamorphosis of Chironomus circumdatus (Kieffer) (Diptera). Aquatic Insects 13: 167-177.

Sentis, A., A. Binzer \& D. S. Boukal, 2017. Temperature-size responses alter food chain persistence across environmental gradients. In Ecology Letters.

Sokolovska, N., L. Rowe \& F. Johansson, 2000. Fitness and body size in mature odonates. Ecological Entomology 25: 239-248.

Stevens, M. M., 1998. Development and survival of Chironomus tepperi Skuse (Diptera: Chironomidae) at a range of constant temperatures. Aquatic Insects 20: 181-188.

Sweeney, B. W., J. K. Jackson \& D. H. Funk, 1995. Semivoltinism, seasonal emergence, and adult size variation in a tropical stream mayfly (Euthyplocia hecuba). Journal of the North American Benthological Society 14: 131-146.

Thomas, C. D., A. Cameron, R. E. Green, M. Bakkenes, L. J. Beaumont, Y. C. Collingham, B. F. N. Erasmus, M. F. de Siqueira, A. Grainger, L. Hannah, L. Hughes, B. Huntley, A. S. van Jaarsveld, G. F. Midgley, L. Miles, M. A. OrtegaHuerta, A. Townsend Peterson, O. L. Phillips \& S. E. Williams, 2004. Extinction risk from climate change. Nature 427: 145-148.

Thompson, D. J., 1975. Towards a predator-prey model incorporating age structure: the effects of predator and prey size on the predation of Daphnia magna by Ischnura elegans. The Journal of Animal Ecology 44: 907-916.

Tokeshi, M., 1995. Production ecology. In Armitage, P. D., P. S. Cranston \& L. C. V. Pinder (eds), The Chironomidae. Springer, Dordrecht.

Tseng, M., K. M. Kaur, S. Soleimani Pari, K. Sarai, D. Chan, C. H. Yao, P. Porto, A. Toor, H. S. Toor \& K. Fograscher, 2018. Decreases in beetle body size linked to climate change and warming temperatures. Journal of Animal Ecology 87: 647-659.

Walsh, P. S., D. A. Metzger \& R. Higuchi, 1991. Chelex ${ }^{\circledR} 100$ as a medium for simple extraction of DNA for PCR-based typing from forensic material. BioTechniques 54: 506-513.

Walther, G.-R., E. Post, P. Convey, A. Menzel, C. Parmesan, T. J. C. Beebee, J. M. Fromentin, O. Hoegh-Guldberg \& F. Bairlein, 2002. Ecological responses to recent climate change. Nature 416: 389-395.

Wonglersak, R., P. B. Fenberg, P. G. Langdon, S. J. Brooks \& B. W. Price, 2020. Temperature-body size responses in insects: a case study of British Odonata. Ecological Entomology 45: 1-11.

Woods, H. A., 1999. Egg-mass size and cell size: effects of temperature on oxygen distribution. American Zoologist 39: 244-252. 
Xue, R. D. \& A. Ali, 1994. Relationship between wing length and fecundity of a pestiferous midge, Glyptotendipes paripes (Diptera: Chironomidae). Journal of the American Mosquito Control Association 10: 29-34.

Yvon-Durocher, G., J. I. Jones, M. Trimmer, G. Woodward \& J. M. Montoya, 2010. Warming alters the metabolic balance of ecosystems. Philosophical Transactions of the Royal Society B: Biological Sciences 365: 2117-2126.

Yvon-Durocher, G., A. P. Allen, M. Cellamare, M. Dossena, K. J. Gaston, M. Leitao, J. M. Montoya, D. C. Reuman, G. Woodward \& M. Trimmer, 2015. Five years of experimental warming increases the biodiversity and productivity of phytoplankton. PLoS Biology 13: e1002324

Zhu, Y., K. J Purdy, Ö. Eyice, L. Shen, S.F. Harpenslager, G. Yvon-Durocher, A. J. Dumbrell \& M. Trimmer, 2020. Disproportionate increase in freshwater methane emissions induced by experimental warming. Nature Climate Change.

Publisher's Note Springer Nature remains neutral with regard to jurisdictional claims in published maps and institutional affiliations. 